\title{
The Tengkolok Heritage of Perak Darul Ridzuan: The Experts, Techniques, Customs \& Taboos
}

\author{
Salina Abdul Manan \\ Institut Alam dan Tamadun Melayu \\ Universiti Kebangsaan Malaysia, 43600 Bangi, Selangor, Malaysia Malaysia \\ E-mail: salina200183@gmail.com \\ Hamdzun Haron \\ Pusat Citra Universiti \\ Universiti Kebangsaan Malaysia, 43600 Bangi, Selangor, Malaysia \\ E-mail: hh@ukm.edu.my \\ Zuliskandar Ramli \\ Institut Alam dan Tamadun Melayu \\ Universiti Kebangsaan Malaysia, 43600 Bangi, Selangor, Malaysia \\ E-mail: ziskandar2109@gmail.com \\ Noor Hafiza Ismail \\ Institut Alam dan Tamadun Melayu \\ Universiti Kebangsaan Malaysia, 43600 Bangi, Selangor, Malaysia Malaysia \\ E-mail: yurizinsen@yahoo.com.my
}

Doi:10.5901/mjss.2016.v7n4p

Abstract

The tengkolok is a unique head covering worn by Malay men and it is still in use today. However, its use is limited to certain cultural events and ceremonies. The purpose of this study is to document, in detail, the experts of Malay tengkolok heritage, especially those who hail from the state of Perak Darul Ridzuan. This paper addresses questions like - who are the tengkolok experts of the state of Perak, what are the tengkolok folding techniques they use and what are the customs and taboos observed in the making of tengkolok? To address these questions, a culturally-sensitive qualitative approach is applied. Interviews and observations were also used in obtaining data, either in writing or visual form. As a result of the observations made, it has been found that there are four tengkolok experts who are still active in the state of Perak. Each expert possesses a different technique in folding the tengkolok, a process called menyolek (literally meaning 'to beautify'). This paper will discuss the tengkolok experts themselves, the folding techniques, customs and taboos in the production of a tengkolok. It is hoped that this research will draw the interest of researchers, especially in the field of Malay clothing, as well as the younger generation, so that they will become familiar with the tengkolok and learn the art of folding the tengkolok. The findings of this study is highly valuable and contributes to the continuation of the artistic heritage of tengkolok folding, which is not well known or appreciated by the younger generation today. Documentation of the tengkolok experts is one way to appreciate the champions of Malay tengkolok heritage.

Keywords: Experts, Techniques, Customs, Taboos, Tengkolok, Perak Heritage

\section{Introduction}

The culture of a people is invaluable and must be inherited by today's community. For the Malays, the unique headdress known as the tengkolok may have begun with the act of tying a piece of cloth around the head to keep the hair in place. But through the passage of time, this tying method evolved according to its provenance and has today become a unique art form by the Malay people (Mohamad Nazri Ahmad, 2000). Masda Mahmud (1994) states that the wearing of the tengkolok is a symbol of national identity. In the past, the wearing of the tengkolok determined one's status and rank. The 
tengkolok is also closely related to the palace and heroism, as well as clothing for official functions and ceremonies (Maruwiah Ahmat, 2012).

This traditional Malay headdress or head covering is very special due to the tying or folding technique used to attach it to the head. The headdress or head covering in question is none other than the tengkolok. The tengkolok is a head cloth, which in the past was worn by members of the royal court, dignitaries and Malay bridegrooms, according to Hamidah Husain and Mohamed Roselan Malek (1995). It is also known by various other names, such as tanjak, destar, semutar, bulang hulu and sapu tangan. The terms used differ according to the Malaysian state, for example in Selangor, it is known as tanjak and in Perak it is known as tengkolok (Azah Aziz, 2006). Although there are many terms used to describe this Malay headdress or head covering, there is only one purpose, which is to cover or protect the head. The tengkolok is a Malay art form that is extremely valuable. The intricacy of this art form encompasses various stories and backgrounds that reflect upon the wearer (Utusan Malaysia, 5 June 2013). It is made manually, by folding and shaping a piece of cloth using the hands and knees. It is impossible to fold and beautify the tengkolok with modern technologies like machines or robots. The skill of folding the tengkolok is usually the preserve of men. According to Mohamad Dzulkarnain Osman, in a personal interview on 6 March 2014, the wearing of the tengkolok began with the daily clothing of the common people. In the beginning, a piece of cloth would be wrapped and tied around the head to keep the hair in place when appearing before the Sultan at the palace. From this simple head wrap, the palace would eventually make the tengkolok part of the official dress, as the act of covering the head was considered neat and proper. From that point on, tengkolok folders began to design various beautiful and interesting tengkolok styles.

The production of various styles of tengkolok reflects upon the high degree of intellect among tengkolok folders/experts of the past. In observing the difficulty of the process of folding and beautifying a tengkolok, it is evident that the artistic skill of a tengkolok expert demands positive characteristics such as diligence, hard work, patience and creativity. Tengkolok experts of the past turned to nature for inspiration when designing a tengkolok, because at the time, there wasn't a specific design reference. Therefore, it can be said that the Malay community of the past was among the first communities to instil elements of innovation in their designs. From a simple piece of cloth tied around the head, they are able to create a unique and specialised art form, which is various forms of tengkolok from just a piece of cloth.

Behind the beauty and uniqueness of these tengkolok designs are dedicated individuals who preserve and uphold the Malay tengkolok heritage. They are the tengkolok experts from Perak, namely Toh Seri Wangsa Haji. Abdul Rahim Mohamad, Mohamad Dzulkarnain Osman, Raja Azizulkhair Raja Harun Al Rashid and Haji Mohd Basri Ngah Mat Ali. Within each of these experts is a wealth of tengkolok folding techniques, such as lipatan 3 jari (three-finger fold), gulungan (rolling) and segi tiga (triangle). Besides these basic techniques, there are also customs and taboos that must be observed when folding and beautifying a tengkolok.

\section{Tengkolok Experts of Perak Darul Ridzuan}

The beauty of the tengkolok heritage of the Perak Sultanate showcases the glorious effort of a select group of individuals who continue to preserve the skills in folding the Malay tengkolok. They are the tengkolok folders/experts, who possess a unique creativity in tengkolok folding. Our observations have revealed that Perak currently has four tengkolok experts who specialise in designing tengkoloks for the Perak Sultanate. They are Toh Seri Wangsa Hj. Abdul Rahim Bin Mohamad, AMP, PKH who is known as Tok Ayah or Pak Tok Ibrahim, Mohamad Dzulkarnain Bin Osman who is known as Pak N or Nain, Raja Azizulkhair Raja Harun Al Rashid who is known as Ku Ayah or Ayah Jed and Haji Mohd Basri Bin Ngah Mat Ali, PJK, PPT who is known as Haji Basnee. Their skills are indispensible, especially when titles and medals are conferred in conjunction with the Sultan of Perak's birthday. During the ceremony, they will receive orders from recipients of medals to prepare the tengkolok, which is an important element of royal ceremonial dress in Perak. The Sultanate of Perak itself boasts of two sultans who were skilled in folding the tengkolok - Al Marhum Sultan Idris Murshidul'adzam Shah I and AI Marhum Sultan Idris Iskandar Al Mutawakkil Shah II.

They are among the individuals who became pioneers in upholding the art of tengkolok folding, which is a vital part of the Sultanate of Perak's heritage. Their efforts and spirit must be emulated by the younger generation so that the continuation of the art of folding the tengkolok may be preserved and passed on through the generations. Each of these experts have their own method and techniques for menyolek (beautifully folding) the tengkolok, which they learnt from various Tuan Guru (Masters), however the first recorded tengkolok folding expert is Al Marhum Sultan Idris Murshidul'adzam Shah I. The differences that are inherent in the basic folding techniques represent the effort of tengkolok experts in elevating and simplifying the art of tengkolok folding, while preserving its artistic heritage. 


\subsection{Toh Seri Wangsa Haji Abdul Rahim Bin Mohamad}

He is 89 years of age and more fondly known as Tok Ayah or Pak Tok Ibrahim. He is also an Orang Besar 16 (royal adviser appointed by the Sultan) and Timbalan Pawang Diraja Kesultanan Perak (Deputy Royal Healer of the Perak Sultanate). Besides his skills in folding the tengkolok, he is also skilled in traditional medicine. Tok Ayah is highly fortunate to have served four ruling sultans - Al Marhum Sultan Yussuf Izzuddin Shah, Al Marhum Sultan Idris Iskandar Al-Mutawakkil Shah II, Al Marhum Sultan Azlan Muhibbuddin Shah and Sultan Dr. Nazrin Muizuddin Shah. He is also among the most important individuals involved in the ceremonial customs of the Perak royal family, especially in ensuring that each age-old tradition is followed accordingly (Utusan Malaysia, 21 June 2011)

According to Tok Ayah, in a personal interview on 1 May 2014, after the rule of Al Marhum Sultan Idris Iskandar AlMutawakkil Shah II, there were no longer any Perak sultans who were skilled in folding the tengkolok and this task fell to a tengkolok expert that the Sultan had appointed. During his rule, the sultan would fold each tengkolok that he wished to wear himself. Therefore, Tok Ayah informally learnt how to fold the tengkolok from Al Marhum Sultan Idris Murshidul'adzam Shah I, while serving at the Iskandariah Palace as Ship Captain. Now 89 years old, Tok Ayah is still able to fold tengkoloks and possesses excellent memory. Tok Ayah upholds the artistic skill of tengkolok folding so that it will not become obsolete due to modernity.

\subsection{Mohamad Dzulkarnain Bin Osman}

Mohamad Dzulkarnain Bin Osman is a staff member of the Iskandariah Palace, Kuala Langsar and he also serves as the Panglima Perang Kanan (Senior War Commander). In the palace, he is given the title Toh Panglima or Pak Toh. At 37 years of age, he has served with the Iskandariah palace since 2000 until today. Throughout his service, he has served as the private assistant to the Sultan for five years, as bentara or Cultural Customs Officer for five years, Panglima Perang Kiri or Hulubalang to the Queen for a year and now as Panglima Perang Kanan who guards the Sultan of Perak's safety. He obtained the skill of folding the tengkolok of the Sultanate of Perak directly from Tok Ayah. More fondly known as Pak $\mathrm{N}$. he is one of the people who were close to Al Marhum Baginda Sultan Azlan Shah during his reign. In the beginning, he served as the personal assistant of Al Marhum Baginda Sultan Azlan Shah, however upon Tuanku's decree, he was tasked with folding Tuanku's tengkolok. According to Pak N, in a personal interview on 6 March 2014, only a select few can fold and beautify the Sultan's tengkolok because whoever does so without the Sultan's permission may receive tulah, or bad luck. This is because all of the Tuanku Sultan's clothing is guarded by supernatural beings, which are a secret of the Perak government.

Pak N is someone who generously shares all the knowledge and skills he has obtained in folding tengkoloks. He welcomes visits from individuals or groups who are interested in Malay heritage, who come to him to learn the art of folding the tengkolok. He holds to the principle that knowledge must be passed on and not kept. He believes that the knowledge he disseminates will continue to develop and can help advance the Malay people.

\subsection{Raja Azizulkhir Raja Harun Al Rashid}

Raja Azizulkhair Raja Harun Al Rashid, who is 74 years old, is fondly known as Ku Ayah or Ayah Jed. He is a former Ketua Panglima (Chief Commander) of Iskandariah Palace. Ku Ayah is also a descendant of Sultan Idris Murshidul'adzam Shah I who was one of the Sultans of Perak who was skilled in tengkolok folding. It is no wonder, therefore, why Ku Ayah is skilled in the art of tengkolok. Renowned for his skills and as a tengkolok expert in Perak, he is often consulted for his expertise. (Harian Metro, 11 January 2011)

He obtained his skills in tengkolok folding indirectly from his brother Ku Norman or Raja Norman Raja Harun AlRashid Ibni Sultan Idris Murshidul'adzam Shah I. Raja Norman Raja Harun Al-Rashid also served as a Panglima (Commander) at the Iskandariah Palace. Ku Aya learnt the techniques by informally observing Ku Norman as he folded tengkoloks. From those observations, he recreated and practiced his brother's folds. Over time, he became interested to learn the art of tengkolok folding. According to Ku Ayah, in a personal interview on 22 May 2014, folding and beautifying tengkolok requires patience and gentleness. This is because in producing a tengkolok, only patience and gentleness will produce a neat and beautiful tengkolok design.

His advice to new tengkolok folders is, if the fold produced does not turn out as intended, then stop the folding process for a while.. Ku Ayah also states that he has taken a month to produce a tengkolok because the cloth given was so soft and it required a higher degree of focus, calmness and gentleness from him. 


\subsection{Haji Mohd Basir Bin Ngah Mat Ali}

Haji Mohd Basir Bin Ngah Mat Ali, who is more fondly known as Haji Basnee is 74 years old. He is one of the few who possess the skill of folding the tengkolok in Perak. He is an ex staff of the Perak Culture Ministry. He is also the Manager of the Selendang Merah Group, SUK Perak. His time at the Perak Culture Ministry contributed to his interest in deepening his skills in folding the tengkolok of the Perak Sultanate. He learnt the skills of folding the tengkolok from Raja Ismail Iskandar who is the younger sibling of Al Marhum Sultan Idris Iskandar Al Mutawakkil Shah II. His giving and humble nature endears him to all who meet him. According to Haji Basnee, in an interview on 21 May 2014, he has a keen interest in the art of Perak tengkolok folding and in continuing it so that it does not become obsolete.

Haji Basnee stated that one way to protect tengkolok designs so that they will not become obsolete is by collecting photos of Perak sultans. By referring to these photos, he will make detailed observations and recreate the forms of those tengkoloks. By doing this, tengkolok that had become obsolete will be revived and the skill will be passed down to the younger generation. He also hopes that the management of Iskandariah Palace Kuala Kangsar will play a role as the main motivator in protecting the identity of Malay tengkolok. Perak sultanate tengkoloks must be protected by maintaining the precision of every tengkolok design.

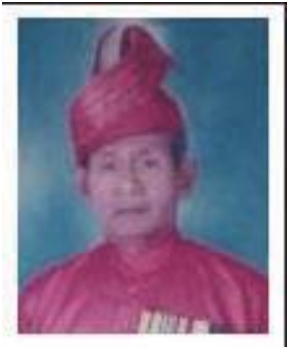

Picture 1: Toh Seri Wangsa Haji Abdul Rahim Bin Mohamad, AMP, PKH

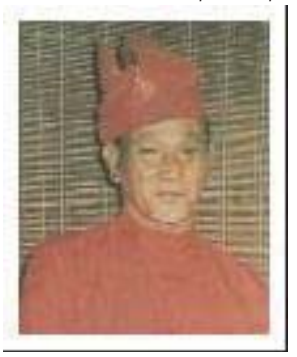

Picture 3: Raja Azizulkhair Bin Raja

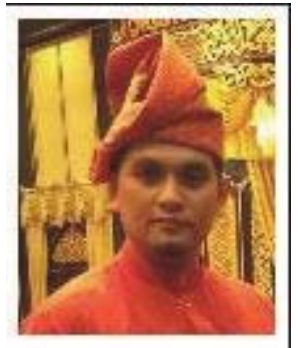

Picture 2: Mohamad Dzulkarnain Bin Osman

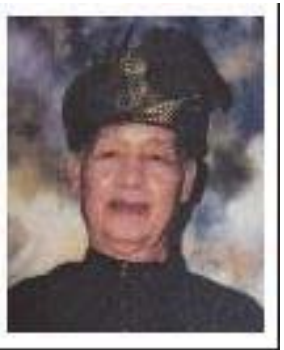

Picture 4: Haji Mohd Basir Bin Ngah Mat Ali, PJK, PPT Osman

\section{Basic Tengkolok Folding Techniques}

Each tengkolok expert has a different technique in folding and beautifying the tengkolok. The basic folding technique that is used by Pak Toh Ibrahim and Mohamad Dzulkarnain Osman is the three-finger technique. Meanwhile, Raja Azizulkhair Raja Harun Al Rashid uses the rolling technique and Haji Basnee uses the triangular fold technique. Each folding technique has its own advantages and uniqueness.

Diagram 1: Classification of basic tengkolok folding techniques

\begin{tabular}{lll}
\hline Num. & Basic folding technique & Expert \\
\hline 1 & Lipatan 3 jari & Haji Abdul Rahim Bin Mohamad \\
& & Mohamad Dzulkarnanin Osman \\
2 & Gulungan & Raja Azizulkhair Raja Harun Al Rashid \\
3 & Lipatan Segi Tiga & Haji Mohd Basir Bin Ngah Mat Ali \\
\hline
\end{tabular}




\subsection{Folding techniques of Toh Seri Wangsa Haji Abdul Rahim Bin Mohamad and Mohamad Dzulkarnain Osman}

The three-finger fold technique begins with laying out the tengkolok cloth into a triangle. After it has been laid out, the tengkolok cloth must be flattened so that there are no bulges on the surface of the cloth. If there are any bulges, the folds will not be very neat. Subsequently, a measurement of three fingers is taken to make the first fold. This first fold will determine the outcome of the next fold. The measurement of this first fold must begin in the centre of the cloth and brought to the end of the cloth. The three finger measurement can be taken horizontally or vertically as in Pictures 7 and 8 below.

After the three finger measurement is taken, the cloth must be folded five times with the same measurement. As a result of the five folds, a small triangle will be formed as in Picture 9. The small triangle measures sejengkal from the tip of the tengkolok cloth. The three-finger fold is used to produce tengkolok designs for commoners. This is because the design of the tengkolok is the same, but the measurement and height cannot be similar to the tengkolok worn by the Tuanku Sultan Perak.

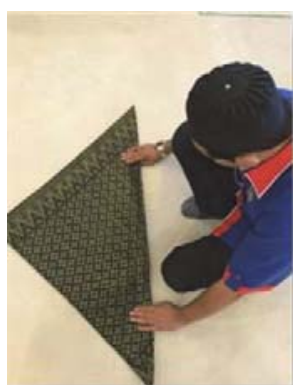

Picture 5: Fold the tengkolok cloth into a triangle

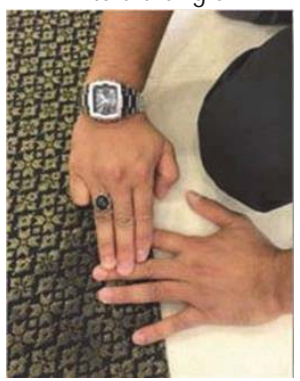

Picture 7: A three-finger measurement is taken horizontally

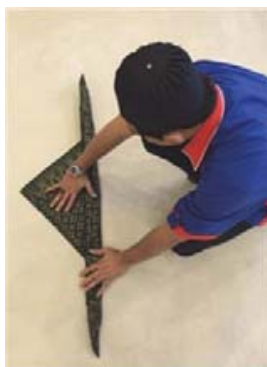

Picture 9: The distance between the tips of the index finger and thumb are measured from edge of the tengkolok cloth

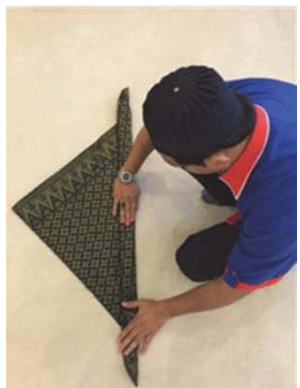

Picture 6: Make the first fold, with a three-

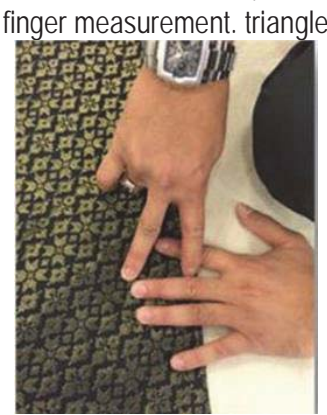

Picture 8: A three-finger measurement is taken vertically

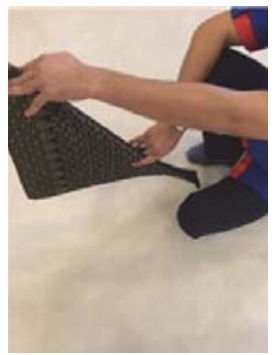

Picture 10: Lift and reverse the tengkolok cloth 
Picture 11: The tengkolok cloth is placed under the right knee cap

\subsection{Basic folding technique by Raja Azizulkhir Raja Harun Al Rashid}

Ku Ayah uses the rolling technique to produce basic tengkolok folds. According to Ku Ayah, in a personal interview on 22 May 2014, the rolling technique makes it easier to fold the tengkolok, as there is no need to count the number of folds needed. There are many ways for someone to make a tengkolok. However, Ku Ayah is able to make a tengkolok in both a standing or seated position. Observations made of Ku Ayah making a tengkolok while standing is captured in the pictures below. Ku Ayah first lays the tengkolok cloth down and the first roll is made, as seen in Picture 12.

This rolling technique does not require you to count the number of rolls to determine the balance at the tip of the cloth. When the tengkolok cloth is rolled and the balance of the tip of the cloth measures sejengkal, then that is the last roll, as in Picture 13. After that, the tengkolok cloth is reversed to face the body and at the same time pressure is made so that the folds will be of the same size, as in Picture 14. A tengkolok cloth that has been completely rolled will be lifted and placed under the right knee, as in Picture 15. Ku Ayah emphasises upon neatness and proper technique in producing a tengkolok.

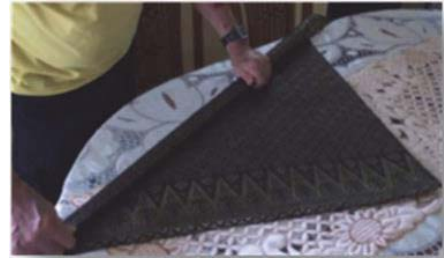

Picture 12: First gulungan

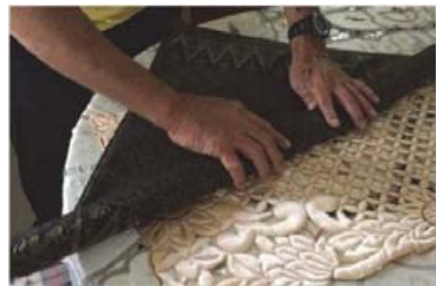

Picture 14: The tengkolok cloth is reversed at the fastening section

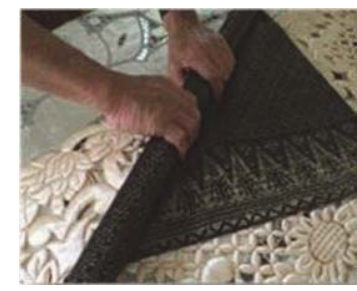

Picture 13: The final fold leaves a small triangle at the top of the cloth

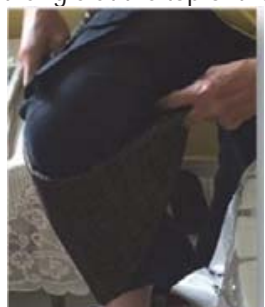

Picture 15: The tengkolok cloth is placed under the right knee

\subsection{Folding technique by Haji Basnee}

Through the observations conducted, it was found that the basic folding techniques used by Haji Basnee are different from the folds used by other experts. Haji Basnee begins the folding technique by laying out the tengkolok cloth and flattening it (Picture 16). After that a three-finger measurement is taken and both hands hold both sides of the cloth, like in 
Picture 17. The tengkolok cloth is folded three times and the balance of the cloth is pulled down to form a triangle, like in Picture 18.

The difference is in the balance of the tengkolok cloth that has been folded. The balance at the tip of the cloth is pulled and folded into a triangle, as in Picture 18. After that, the tengkolok cloth is lifted and placed under the knee in a seated position (legs folded together) like in Picture 19.

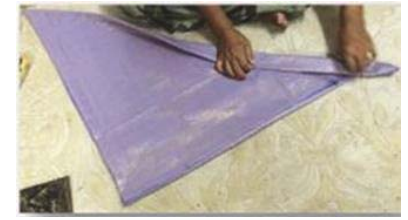

Picture 16: The first fold is made to a tengkolok cloth that has been laid out

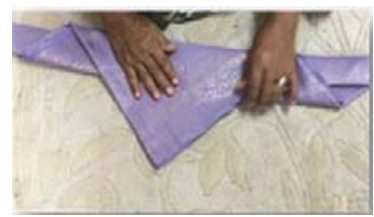

Picture 18: The tengkolok cloth is folded into a triangle

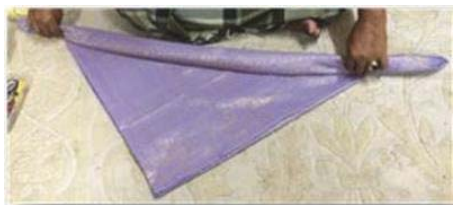

Picture 17: Both hands are needed to hold the edges of the fold

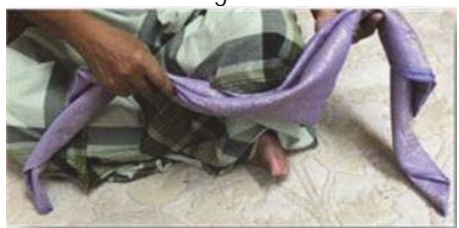

Picture 19: The tengkolok cloth is placed under the knee

\section{Customs observed when making tengkolok}

The Malays are known for their customs and manners. Therefore, in making the tengkolok there are certain customs to be observed so that everything that is done is blessed by Allah Subhanawa Taala. According to Haji Basnee, in a personal interview on 21 May 2014, there are several customs that be observes when making the tengkolok. He begins by reciting the bismillah, the surah Al-Fatihah and selawat for the Prophet Muhammad Sallallah Alaihiwassalam, as well as stating his intention.

He also emphasises that tengkolok makers do not invoke spirits, as it is syirik (against the teachings of Islam). Tengkolok making has no relation to superstitions because the bismillah and selawat for Prophet Muhammad Sallallah Alaihiwassalam is better and blessed by God, Raja Azizulkhir Raja Harun Al-Rashid, personal interview (22 May 2014).

\section{Taboos in making tengkolok}

Everything that is related to the Malay people cannot be excluded from sentiments of taboo. There are numerous taboos in the daily life of a Malay community, for example, an unmarried lady cannot sit on the stairs, as she may receive a marriage proposal later in life. The taboos that were put in place by our ancestors are unique, for example, they sought to protect the manners and etiquette of young women.

The same applies to the art of tengkolok folding, there are several taboos that must be observed. According to Ku Ayah in a personal interview on 22 May 2014, when folding and beautifying the tengkolok, one must take care not to place it at the feet. This is because the tengkolok is worn on the head like a songkok or kopiah, therefore it is improper for it to be stepped on with the feet. If when folding and shaping the tengkolok with the hands does not produce good folds, then use the knee to apply pressure

\section{Conclusion}

The art of tengkolok folding is an artistic skill of the Malay community, which should be protected. It is also a unique heritage and highly-valuable treasure. Therefore, all parties must be responsible in sustaining the art of tengkolok folding. The young generation is among the target groups that must be given attention in inheriting this skill. There are no conditions which state that only courtiers should learn the art, what is important is that the Malay people still love their homeland and Malay artistic heritage. Therefore, today's young generation is encouraged to learn the skills in order to pass them on from one generation to the next 


\section{Personal Interviews}

Abdul Rahim Bin Mohamad. 21 Mei 2014. Ipoh. Perak Darul Ridzuan Mohamad Dzulkarnain Osman. 6 Mac 2014. Istana Iskandariah Kuala Kangsar.

Mohd Basir Bin Ngah Mat Ali. 1 Mei 2014. Ipoh, Perak.

Raja Azizulkhair Raja Harun Al Rashid. 22 Mei 2014. Ipoh. Perak

\section{References}

Azah Aziz. (2006). Rupa dan Gaya: Busana Melayu. Kuala Lumpur. Universiti Kebangsaan Malaysia

Hamidah Husain. Mohamed Roselan Malek. (1995). Pakaian dan PerhiasanTradisional. Selangor Darul Ehsan. Prisma Sdn. Bhd. Maruwiah Ahmat. (2012). Pakaian Tradisional. Get Smart Publications Sdn. Bhd.

Mohamad Nazri Ahmad. (2000). Tembikar da Tengkolok. Pustaka Mawar.

Masda Mahmud. (1993). Tengkolok Sebagai Lambang Status Golongan Istana.Universiti Teknologi MARA. Shah Alam. Selangor Harian Metro. 11 Januari 2011.

Utusan Malaysia. 21 Jun 2011. 5 Jun 2013. 